\section{Applied Psychology in Italy}

A Permanent Commission for the Application of Psychology has recently been appointed by the Italian National Board of Researches. It aims at promoting among State institutions, labour organiza. tions and private persons the application of psychology in any field, with regard to selection and orientation, as well as to the organization of work. At present, applications in the scholastic field, where professional orientation has become a function of the school, are being studied in the first place ; applications in industries, aviation and public transport will follow. The president of the Commission is Prof. P. Agostino Gemelli.

\section{Appointments for Research in Tropical Medicine}

TнE Medical Research Council is offering up to three junior fellowships to qualified medical men or women wishing to receive training with a view to careers in research work in tropical medicine. The fellowships will be tenable for three years. The stipend will be at the rates of $£ 300, £ 400$ and $£ 500$ per annum in the successive years, with an additional allowance during service abroad and necessary expenses. In three years' time, at least one senior fellowship will be available for candidates who have held the junior fellowships mentioned above. This will be awarded for a further period of three years, carrying stipend at the rate of $£ 600-£ 750$ per annum, with an additional allowance during service abroad and expenses. The Council is also prepared to consider immediate applications for senior fellowships from candidates who have had adequate experience in research work, whether already specially trained in tropical medicine or not. The Council further intends to establish in due course, as suitable investigators become available as the result of the fellowships scheme, permanent and pensionable appointments for research work in tropical medicine, including senior posts. Further information can be obtained from the Secretary, Tropical Medical Research Committee, 38 Old Queen Street, London, S.W.I, with whom applications should be lodged not later than June 19, 1939.

\section{Announcements}

Sir Edward Mellanby, secretary of the Medical Research Council, will deliver the annual Stephen Paget Memorial Lecture of the Research Defence Society on the occasion of the Society's annual general meeting, to be held at the London School of Hygiene and Tropical Medicine on June 13. The title of Sir Edward's lecture will be "The Experimental Method in the Conquest of Disease".

THE seventy-sixth annual general meeting (Murdoch Centenary) of the Institution of Gas Engineers will be held on June 6-9 at the Institution of Civil Engineers. The Murdoch Centenary Lecture will be delivered on June 6 by Dr. E. F. Armstrong.

THE Council of the Institution of Naval Architects has accepted an invitation of the Gesellschaft der Freunde u. Förderer der Hamburgischen Schiffbau-
Versuchsanstalt to participate in an International Meeting of Shipbuilders, Marine Engineers and Nautical Experts to be held in Hamburg in June. A visit will be paid to Kiel at the invitation of the German Navy, and two days will also be spent in Berlin under the auspices of the Lilienthal-Gesellschaft für Luftfahrtforschung and of the Schiffbautechnische Gesellschaft.

The Cambridge University Press has in active preparation, and will publish early in the autumn, the authorized biography of the late "Lord Rutherford", by Prof. A. S. Eve, a personal friend for many years and formerly Macdonald professor of physics at MeGill University. The author has enjoyed the fullest co-operation of Rutherford's closest colleagues and friends, and of Lady Rutherford, who has allowed use to be made of the collection of her husband's letters and papers. Earl Baldwin has written a foreword.

THE Institute of Ethnography attached to the Academy of Sciences of the U.S.S.R. is preparing an ethnographical work on the different peoples of the U.S.S.R. which will run into many volumes. The first three volumes are to be ready this year, and will be devoted to a description of the peoples of Central Asia and Kazakhstan, Siberia and the Far East, and the European section of the Soviet Union. The Institute for Soil Study of the Academy has just published the first three volumes of a monograph on "Soils of the U.S.S.R.". These volumes contain a geographical description of the soil of the European part of the U.S.S.R. from the far north to the Caucasus. A fourth volume, dealing entirely with the soils of the Caucasus, will be issued this year.

The German Society of the History of Medicine, Natural Science and Technique will be held this year at Jena on September 21-24, when the chief subjects for discussion will be the eye in the history of medicine, natural science and technique. There will also be an exhibition of historical collections in Jena and Weimar.

Eleven thousand fewer persons were killed in accidents of all kinds in the United States during 1938 than in 1937 - a decline of more than 10 per cent. Motor-vehicle fatalities declined from about 40,000 in 1937 to between 31,000 and 32,000 in 1938.

Precmminary figures from the census taken in Soviet Russia last January give the U.S.S.R. a population of $170,126,000$. The increase since 1926 is $23,100,000$, which is approximately equal to the population of Spain. In Moscow the birth-rate was 69 per cent higher in 1938 than in 1936 : the deathrate for the entire country has dropped by more than 40 per cent compared with 1913. The census shows that the total number of industrial workers employed in the U.S.S.R. rose from $11,600,000$ in 1928 to $27,800,000$ in 1938. The entire population has more than doubled since 1926. 